\title{
Doctors seek lost data on Alzheimer's vaccine
}

\section{Alison Abbott, Munich}

Data on the first experimental vaccine for Alzheimer's disease are being lost because the patients who were immunized are no longer being monitored.

Trials of the vaccine were abandoned for safety reasons in January 2002, but researchers in Switzerland say that much could still be learned from the patients who received the shots. "A unique biological resource" is being wasted, says Roger Nitsch, a neuroscientist from the University of Zurich who worked on the study.

The trial was launched in 2001 by the San Francisco arm of drug company Elan, which recruited 372 Alzheimer's sufferers in the United States and Europe. Participants received between one and three of six planned inoculations before evidence of brain inflammation halted the study.

The premature end of the trial dealt a blow to the concept of a vaccine for Alzheimer's, but the approach remains one of the few potentially viable options for controlling the disease (see Nature 422, 370-372; 2003).

Although Elan followed the subjects until December 2002, once the trial had stopped neither the company nor any of the participating research centres were obliged to follow the patients. Of the 28 groups who provided patients for the trial, only Nitsch and his colleagues continued to study the subjects. His group has intriguing data on his patients, who now number 13 , and says it would be a "great opportunity" to study other subjects from the trial.

Thelack of follow-up is not unusual for this level of clinical trial. But some researchers say a longer assessment should have been made in this case, because of the long-term effects of immunization. At present, no agency has the power to intervene to ensure such studies happen, although the US Food and Drug Administration can insist on the creation of long-term follow-up registers for some of the treatments it licenses, such as gene therapies.

Elan did not respond to requests for an interview, but the company last month presented results of its limited follow-up at the International Conference on Alzheimer's Disease and Related Disorders, held in Philadelphia. About a fifth of those immunized developed antibodies to amyloid- $\beta$ protein, the main constituent of the destructive brain plaques that occur in Alzheimer's. But an alarming and unexplained brain shrinkage, averaging $6 \%$ in volume, was also seen in these patients. In addition, they showed no clear-cut improvement in cognitive function.

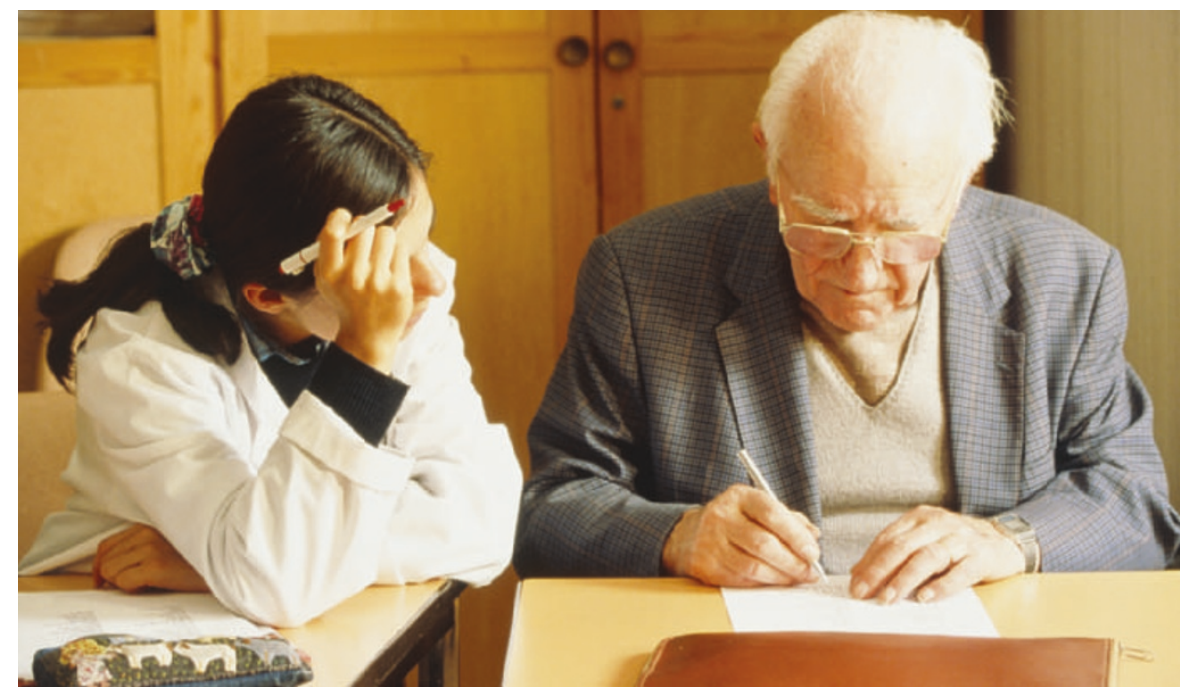

Long-term assessment of an Alzheimer's vaccine suggests it may improve performance in cognitive tests.
The results from Nitsch's group, also discussed at the meeting, were more positive. The researchers said that patients regained some of the lost brain volume in the second year after vaccination and, using a more sophisticated test than that used by Elan, they said that they had found a correlation between cognitive improvement and the level of antibodies to amyloid- $\beta$.

Nitsch is now using this technique to look for a similar link in blood samples taken by Elan from all trial patients before the study was halted. He also plans to contact all the participating centres to ask whether they will collaborate on similar tests. But each new study will require fresh ethical approval and the sourcing of new funds - exercises that could be difficult for individual researchers such as Nitsch to coordinate.

\section{Petition fails to reverse massive price rise for AIDS drug}

\section{Erika Check, Washington}

The US National Institutes of Health (NIH) has declined to impose a price cut on a key AIDS medicine.

The refusal to accede to complaints about drug costs, made after drug firm Abbott Laboratories hiked the price of one of its AIDS medications by more than $400 \%$, won praise from research universities.

"Pharmaceutical pricing is an issue, but marching in on a company's patent is not the appropriate way to deal with it," says Patrick White, director of federal relations at the Association of American Universities in Washington. The association feared that NIH intervention would deter companies from commercializing scientific findings.

The NIH's decision stemmed from a petition filed in January by Essential Inventions, a Washington-based patent watchdog (see Nature 429, 6; 2004). The group was protesting about the cost of Abbott's Norvir, which is used to boost the effectiveness of other AIDS therapies. Abbott, based in Abbott Park, Illinois, raised the price in December from $\$ 1.71$ to $\$ 8.57$ a day.

Critics alleged that the move was designed to push patients towards Abbott's combination pill, Kaletra, which contains Norvir but was not subject to the price increase.

Essential Inventions asked the NIH to invoke laws to make the drug available in generic form. The agency can do this to patented inventions developed with $\mathrm{NIH}$ funds if they are not being made available under "reasonable" terms.
But on 4 August, Bonny Harbinger of the NIH's Office of Technology Transfer said that Norvir is already available to the public on reasonable terms, as it is marketed by Abbott and prescribed by physicians. "We think the issue of drug pricing is appropriately left for Congress and the administration to address legislatively," Harbinger said.

The ruling has angered AIDS patients, watchdog groups and some politicians, who vowed to fight for lower drug prices. They add that the Norvir debate has put the issue of the escalating costs of prescription drugs on the political agenda in the run-up to this November's presidential election. "This will encourage patent owners to price their products more aggressively," says James Love, president of Essential Inventions. 